\title{
СТЕНДОВІ ВИПРОБУВАННЯ КОЛІСНИХ ПАР РЕЙКОВОГО ТРАНСПОРТУ
}

\author{
Ракша С. В., Куроп'ятник О. С.
}

\section{ВСТУП}

У багатьох галузях промисловості широкого розповсюдження набули засоби рейкового транспорту. Вони використовуються для транспортування вантажів і людей у межах підприємства, кар'єру чи шахт (внутрішній промисловий транспорт) або забезпечують сполучення окремих підприємств (зовнішній промисловий транспорт, у тому числі залізничний).

Кожен із засобів рейкового транспорту має у своєму складі візок, який містить, зокрема, колісну пару (далі - КП). Це складальна одиниця, що містить вісь КП як базову деталь, ходові колеса (або одне колесо - для піввісей) і зубчасте колесо (для приводних осей).

Для проведення лабораторних випробувань колісних пар рейкового транспорту, визначення характеристик міцності й ресурсних характеристик їх елементів, порівняння ефективності конструктивних рішень і проведення приймальних випробувань доцільно застосовувати стендове обладнання, що дозволить максимально оцінити різні властивості КП. Тому тематика досліджень, яка пов'язана зі створенням та удосконаленням конструкцій стендового обладнання для експериментальних досліджень колісних пар, $є$ актуальною науковоприкладною задачею для залізничного транспорту й транспортного машинобудування.

Рядом нормативних документів ${ }^{1}$ передбачено такі види випробувань: приймально-здавальні, періодичні й типові. Серед контрольованих параметрів - допуски форм і розмірів поверхонь елементів КП, динамічний дисбаланс, значення остаточних зусиль запресування та натягу в спряженнях елементів КП, електричний опір, параметри міцності деталей КП та їх спряжень тощо.

1 ГОСТ 11018-2011. Колесные пары тягового подвижного состава железных дорог колеи 1520 мм. Общие технические условия. Москва, 2012. 27 с.

ГОСТ 4835-2013. Колесные пары железнодорожных вагонов. Технические условия. Москва, 2014. 32 с.

ГОСТ 31847-2012. Колесные пары специального подвижного состава. Общие технические условия. Москва, 2013. 23 с. 
До основних видів стендових випробувань колісних пар можна віднести визначення статичних і динамічних показників міцності їх елементів (коліс, осей), серед яких ${ }^{2}$ запаси міцності коліс та осей під дією статичних вертикальних i бокових навантажень (в окремих випадках - ще й дотичних навантажень, граничних за зчепленням), монтажні напруження, залишкові напруження від термічного гартування, межі витривалості деталей КП.

У роботі розглянемо особливості проведення стендових випробувань колісних пар із метою визначення показників втомної міцності їх елементів.

\section{1. Стендові випробування коліс}

Аналіз даних експлуатації та результати теоретичних досліджень свідчать, що безпека руху й основні техніко-економічні показники рейкового рухомого складу суттєво залежать від виникнення та накопичення деформаційних пошкоджень у колесах у процесі експлуатації. Відповідні імітаційні дослідження та натурні випробування проводяться, як правило, на математичних і фізичних моделях у лабораторних умовах, у тому числі й за допомогою каткових стендів із натурними або масштабними одиницями рейкового рухомого складу, на ділянках залізниць із наявними типами й моделями рухомого складу. На каткових стендах відтворюються водночас основні геометричні й фізичні параметри умов експлуатації колісних пар, їхнього технічного стану, а також відповідні характеристики верхньої будови колії, в тому числі й моделюють геометричні відхилення, які викликають відповідні реакції в рухомому складі.

На відміну від американського підходу до оцінки міцності залізничних коліс ${ }^{3}$, європейська й українська процедури допуску коліс до експлуатації, крім розрахунків, передбачають обов'язкове проведення стендових випробувань.

Вітчизняні норми регламентують дві схеми випробувань на втому, які своєю чергою не альтернативні. Під час кваліфікації колісних пар випробування проводяться за описаним вище методом вигину 3 обертанням, але на базі 20 млн циклів ${ }^{4}$. Під час підтвердження якісних

${ }^{2}$ ГОСТ 31373-2008. Колесные пары локомотивов и моторвагонного подвижного состава. Расчеты и испытания на прочность. Москва, 2009. 13 с.

ГОСТ 33783-2016. Колесные пары железнодорожного подвижного состава. Методы определения показателей прочности. Москва, 2016. 58 с.

${ }^{3}$ Specification M-107/M-208. Wheels, Carbon Steel. AAR Manual of Standards and Recommended Practices. Wheels and Axles. 2011. P. 21-60.

${ }^{4}$ ГОСТ 31373-2008. Колесные пары локомотивов и моторвагонного подвижного состава. Расчеты и испытания на прочность. Москва, 2009. 13 с. 
характеристик коліс вимогам стандартної технічної специфікації випробування проводяться з використанням гідравлічного пульсатора під час дії вертикального циклічного навантаження 3 коефіцієнтом асиметрії 0,1 на базі 5 млн циклів (рис. 1). В останньому випадку визначення напруженого стану колеса не обов'язкове й проводиться факультативно, оскільки як критерій випробувань виступає максимальне значення вертикального навантаження. Випробування за такою схемою проводитися без напресування колеса на вісь.

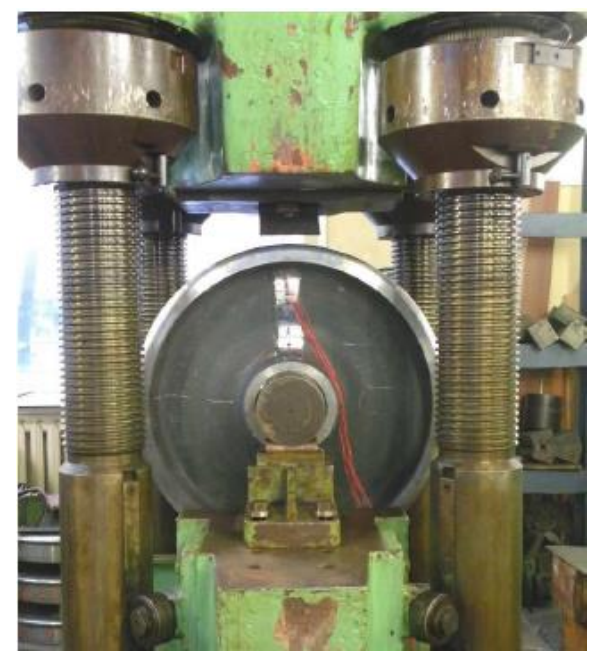

Рис. 1. Гідравлічний пульсатор для випробувань залізничних коліс на втомну міцність

Альтернативою гідравлічному пульсатору $\epsilon$ запропонований авторами стенд для випробувань залізничних коліс на втомну міцність (рис. 2$)^{6}$, який складається 3 основи 1 , на якій закріплений привод 2 , стійки 3, 4, 5. На стійках 5 на осі встановлено колесо 9, що випробовується. На стійках 4 шарнірно закріплено основний двоплечий важіль 6 , який одним плечем контактує 3 колесом 9, а іншим плечем через тягу 7 взаємодіє 3 проміжним важелем 8, шарнірно закріпленим на стійках 3, тоді як тяга 7 приєднується до важелів 6 і 8 шарнірно. Тяга 7 виконується складеною 3 можливістю регулювання іiі довжини.

${ }^{5}$ ГОСТ 10791-2011. Колеса цельнокатаные. Технические условия. Москва, 2011. $27 \mathrm{c}$.

${ }^{6}$ Стенд для випробувань залізничних коліс на втомну міцність : пат. 136718 Україна ; опубл. 27.08.2019. 
Підшипниковий вузол 12 своїм стрижнем приєднаний до демпфера 13 , який з'єднується з вільним кінцем важеля 8 через датчик навантаження 14. У підшипниковому вузлу 12 розташовано ексцентрик 11 , який нерухомо з'єднаний із валом 10 приводу 2.
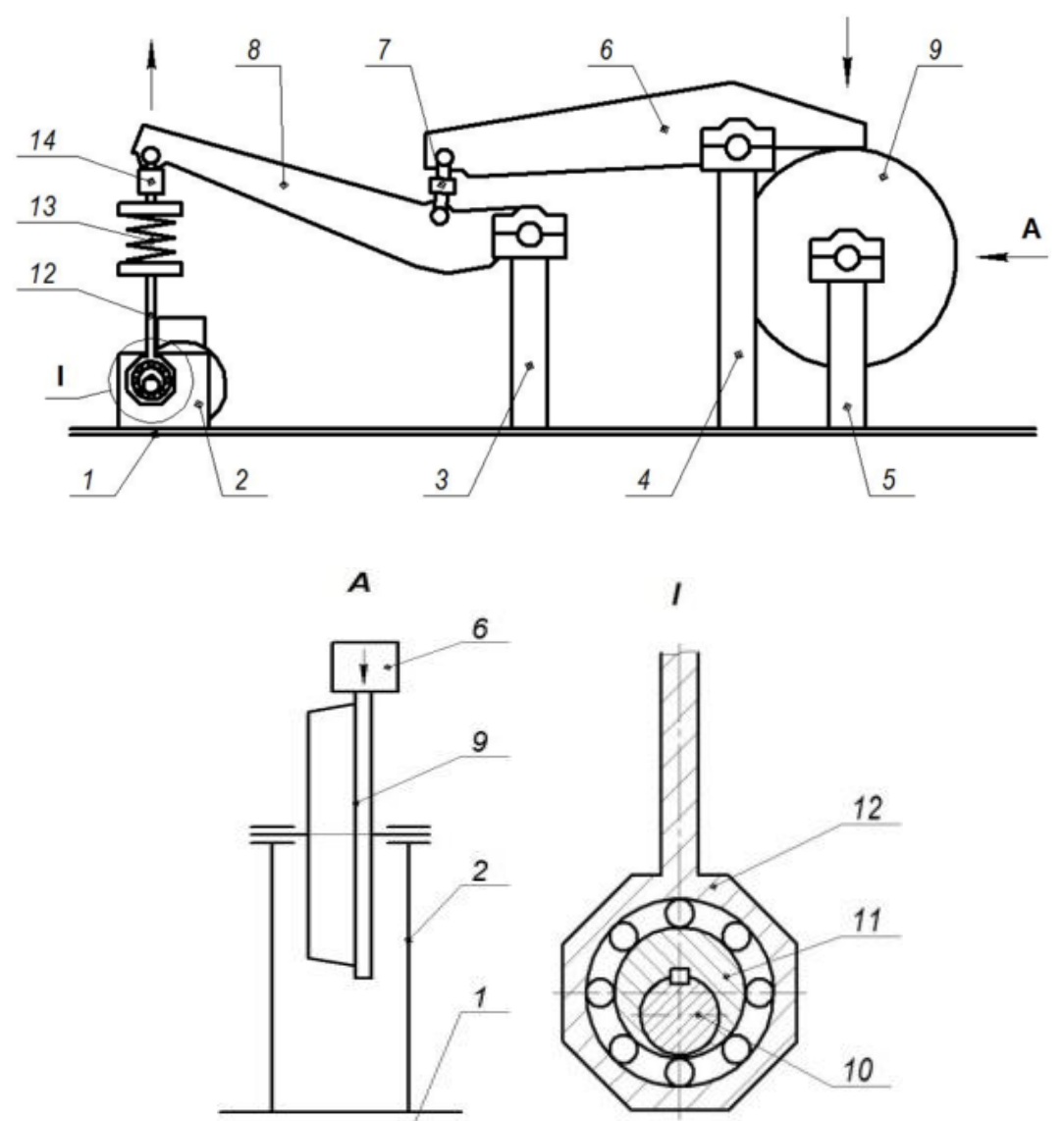

Рис. 2. Стенд для випробувань залізничних коліс на втомну міцність:

1 - основа; 2 - привод; 3, 4, 5 - стійки; 6 - основний важіль; 7 - тяга змінної довжини; 8 - проміжний важіль; 9 - колесо, що випробовується;

10 - вал приводу; 11 - ексцентрик; 12 - підшипниковий вузол;

13 - демпфер; 14 - датчик навантаження

Принцип дії стенду для випробування коліс полягає в такому. Під дією приводу 2 через ексцентрик 11 стрижень підшипникового вузла 12 отримує циклічні вертикальні переміщення, а важіль 8 здійснює 
коливальний рух щодо шарнірного кріплення на стійках 3 . Від важеля 8 через тягу 7 коливальний рух передається на основний важіль 6, вільний кінець якого знаходиться в контакті 3 колесом 9, що випробовується. Внаслідок коливального руху зусилля від важеля 6 у місці контакту з колесом $9 є$ змінним у часі, а отже, забезпечується циклічність навантаження колеса 9, що дозволяє досліджувати показники втомної міцності.

Зміною довжини тяги 7 забезпечується необхідний контакт важеля 6 із колесом 9. Значення зусиль, якими навантажується колесо, контролюється за допомогою датчика навантаження 14. Пружинний демпфер 13 компенсує неточності виготовлення та монтажу стенда, а також пружні деформації, які виникають під час його експлуатації.

Стенд забезпечує випробування залізничного колеса на втомну міцність із контролем циклічного навантаження. Використання проміжного важеля дозволяє зменшити зусилля в шарнірноважільній системі й навантаження на привод, а отже, зменшити габарити й масу стенду. Простота виконання стенду забезпечує його надійність.

На основі зробленого аналізу конструкції основних вузлів стендового обладнання 3 урахуванням нормативних вимог фахівцями Проєктно-конструкторського технологічного бюро Дніпровського національного університету залізничного транспорту імені академіка В. Лазаряна розроблено ескізний проєкт стенду для випробування вагонних коліс на втомну міцність (рис. 3). Стенд призначено для проведення механічних випробувань залізничних коліс рейкового рухомого складу з метою визначення показників втомної міцності. Область застосування стенда - транспортне машинобудування та залізничний транспорт, устаткування для виконання експериментальних досліджень елементів колісних пар рейкового транспорту.

Стенд для випробувань залізничних коліс на втомну міцність, наведений на рис. 3, 3 приводом, наведеним на рис. 4, складається 3 електродвигуна 3 редуктором 1 , консольно закріпленими на редукторі 2, на якому розташовані два ексцентрикові вали 3 з вальничними вузлами 4. На ексцентрикових валах встановлено шатуни 5 , у верхній частині яких розміщено балансири 6 , з'єднані між собою вальничними вузлами 7. Середню частину балансира з'єднано зі штоком 8 за допомогою шарнірної вальниці 9. На штоку кріпиться нижня опора 10 пружинного демпфера 11, сила тиску якого контролюється сенсором зусилля 12 , яке підбирається таким чином, щоб коефіцієнт асиметрії пружинного демпфера був 0,1 . 


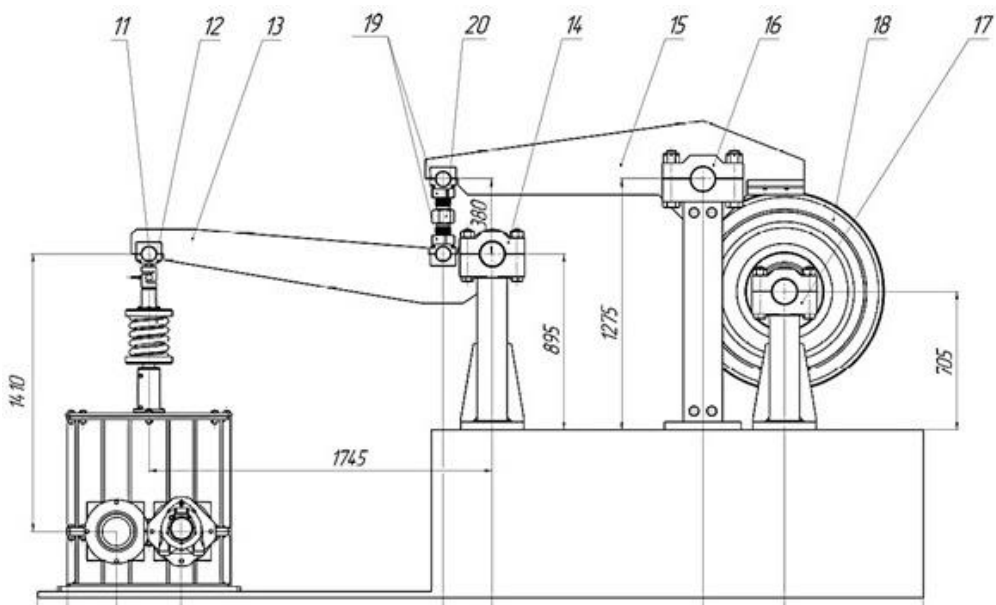

Рис. 3. Стенд для випробувань вагонних коліс на втомну міцність:

11 - пружинний демпфер; 12 - сенсорне зусилля; 13 - проміжний важіль;

14 - стійки опори проміжного важеля; 15 - основний важіль;

16 - стійки опори основного важеля; 17 - стійки опори випробувального колеса; 18 - випробувальне колесо; 19 - регулювальний болт; 20 - регулювальні гайки
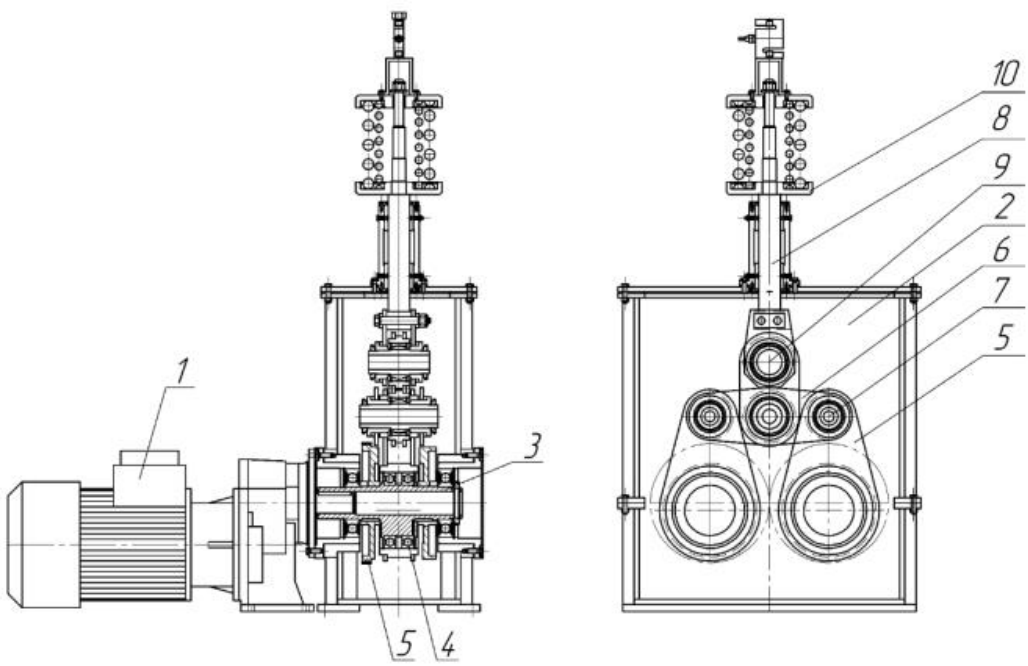

Рис. 4. Привід стенду для випробувань вагонних коліс на втомну міцність: 1 - електродвигун із редуктором; 2 - редуктор; 3 - ексцентриковий вал;

4 - вальничні вузли; 5 - шатун; 6 - балансир; 7 - вальничні вузли; 8 - шток; 9 - шарнірна вальниця; 10 - нижня опора 
Зусилля передається через плече проміжного важеля 13, який закріплений двома стійками опори 14 проміжного важеля, далі через пари регулювального болта 19 і гайок 20 на основний важіль 15, двома стійками опори основного важеля. Всі стійки опор нерухомо закріплені до основи. Плече сили $є$ ефектом добутку довжин плечей, а загальна довжина реалізується сумарною дією реакції взаємних переміщень 15 щодо 13. Регулювання плеча сили здійснюється шляхом зміни вильоту трапецеїдальної пари 19-20. Випробовуване колесо 18 монтується на вісь, яку закріплено на двох стійках 17. Стійки мають можливість переміщуватися для зміни зусилля впливу на колесо.

Стенд працює таким чином: для випробування залізничного колеса 18 на втомну міцність на основному важелі 15 закріплено навантажувач, що тисне зі змінною в часі заданою силою 3 коефіцієнтом асиметрії 0,1 визначену кількість циклів.

Електродвигун із редуктором 1 через редуктор 2 впливає на вертикальне переміщення штока. Після цього $є$ можливість вертикального руху пружинного демпфера 11 , за допомогою сенсору зусилля 12 отримуємо дані про силу тиску, що далі передається на дволанкову систему важелів 13 і 15.

Випробування проводиться за вказаним діапазоном зусилля та iз зазначеною кількістю 5 млн циклів навантажень. Після випробування колесо підлягає подальшим дослідженням та аналізу результатів за спрацюванням і утворенням тріщин, залишкових деформацій.

Описана конструкція випробувального стенда не вимагає спеціального обладнання, дорогих компонентів і матеріалів, що дозволило спростити конструктивне рішення складових вузлів і стенду в цілому, здешевити його виготовлення.

\section{2. Стендові випробування осей колісних пар}

Безпека експлуатації засобу рейкового транспорту безпосередньо залежить від міцності базової деталі колісної пари - іiі осі. Тому останнім часом проводяться численні дослідження теоретичного й експериментального характеру як для засобів рейкового транспорту ${ }^{7}$, так і для машин, що містять рейкове ходове обладнання ${ }^{8}$.

${ }^{7}$ Novosad M., Fajkoš R., Řeha B., Řezníček R. Fatigue tests of railway axles. Procedia Engineering. 2010. № 2. C. 2259-2268. URL: https://doi.org/10.1016/ j.proeng.2010.03.242.

Raksha S., Anofriev P., Kuropiatnyk O. Simulation modeling of the rolling stock axle test-bench. E3S Web of Conferences. 2019. № 123. Art. No. 01032. URL: https://doi.org/10.1051/e3sconf/201912301032.

${ }^{8}$ Raksha S.V., Anofriev P.G., Bohomaz V.M., Kuropiatnyk O.S. Mathematical and Smodels of cargo oscillations during movement of bridge crane. Naukovyi Visnyk 
Перед складанням колісної пари здійснюються випробування певної кількості осей із партії. Для цього використовується спеціальне обладнання, зокрема, випробувальні стенди, які імітують прикладання сил, еквівалентних до робочих навантажень.

Відповідно до міждержавного стандарту ${ }^{9}$, для осей колісних пар встановлено такі види стендових випробувань:

- випробування під час навантаження статичними вертикальними й боковими горизонтальними силами;

- випробування під час навантаження дотичними силами 3 граничними за зчепленням значеннями з урахуванням боксування;

- випробування на втомну міцність під час навантаження циклічним круговим згинанням.

Останній із видів випробувань найскладніший, оскільки передбачає роботу стенда в умовах суттєвих динамічних навантажень. Було проведено чимало досліджень із питань встановлення раціональної схеми навантаження, визначення конструктивних та експлуатаційних параметрів стенда. Результати таких досліджень набули відбиття в ряді охоронних

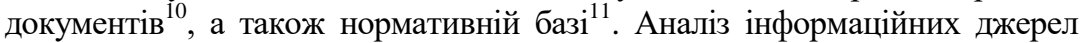
показав, що проблема розробки раціональної конструкції та обгрунтування параметрів стенда для випробувань на втомну міцність осей колісних пар рейкового транспорту актуальна, однак і досі не розв'язана.

$\mathrm{y}$ межах роботи виконаємо обгрунтування основних параметрів стенда для випробувань на втомну міцність осей колісних пар рейкового транспорту.

Для досягнення поставленої мети необхідно розв'язати такі задачі:

1) обгрунтувати раціональну схему навантаження під час стендових випробувань;

2) встановити залежність робочого зусилля стенда від параметрів осі КП, яка випробовується;

Natsionalnoho Hirnychoho Universytetu. 2019. № 2. C. 108-115. URL: https://doi.org/10.29202/nvngu/2019-2/16.

${ }^{9}$ ГОСТ 31373-2008. Колесные пары локомотивов и моторвагонного подвижного состава. Расчеты и испытания на прочность. Москва, 2009. 12 с.

10 Установка для испытания осей колесных пар на усталость при круговом изгибе : пат. 1076816 СССР ; опубл. 28.02.1984.

Стенд для испытания колес и осей колесных пар на сопротивление усталости : пат. 2650327 Россия ; опубл. 11.04.2018.

Стенд для испытания колес и осей колесных пар на сопротивление усталости и способ проведения испытаний : пат. 2651629 Россия ; опубл. 23.04.2018.

${ }^{11}$ ГОСТ 33200-2014. Оси колесных пар железнодорожного подвижного состава. Общие технические условия. Москва, 2015. 42 с.

ГОСТ 33783-2016. Колесные пары железнодорожного подвижного состава. Методы определения показателей прочности. Москва, 2016. 58 с. 
3) обгрунтувати конструкцію вібратора - джерела робочого зусилля стенда;

4) визначити параметри вібратора.

Для отримання та аналізу результатів використано методи математичного моделювання із залученням спеціалізованих програмних комплексів.

\section{1. Обгрунтування раціональної схеми навантаження}

Загальні вимоги до проведення стендових випробувань на втомну міцність осей КП наведено в міждержавному стандарті ${ }^{12}$. Згідно із цим стандартом, передбачається встановлення осі КП на дві шарнірні опори, одну з яких розташовують щонайближче до торця буксової шийки, а іншу - на ділянці між поверхнями встановлення ходових коліс (рис. 5a). Водночас робоче зусилля стенда $\left(F_{1}\right)$ діє в радіальному напрямку на поверхню встановлення ходового колеса, яка знаходиться між опорами. У такому випадку схему навантаження можна подати як балку на двох шарнірних опорах із поперечною зосередженою силою між ними (рис. 5б). Стандартом не регламентується величина цієї сили, а розміри балки вказуються залежними від конструкції та типу осі.

B іншому міждержавному стандарті ${ }^{13}$ зазначено, що циклічне кругове згинання осі КП має бути реалізовано шляхом обертання неврівноваженої маси, встановленої на буксовій шийці (місце розташування шарнірної нерухомої опори на рис. 5а). Водночас сама вісь має бути запресована в ходове колесо (або технологічну маточину, встановлену замість колеса), яке зафіксовано від будь-яких переміщень (рис. 6а). За таких умов схема навантаження $\epsilon$ балкою, защемленою 3 одного боку, до консолі якої прикладено зосереджену силу $F_{2}$ (рис. 6б). Величину цієї сили, як і в попередньому випадку, не регламентовано, геометричні параметри схеми залежать від розмірів осі КП.

Зауважимо, що в разі проведення випробувань за схемою рис. 5 або рис. 6 на стенді встановлюється лише частина осі КП.

Слід також відзначити ще дві схеми навантаження осі, які більшою мірою відповідають реальним умовам використання колісної пари. Кожна 3 них грунтується на представленні осі КП як балки на двох шарнірних опорах. В одному випадку опорні точки розташовуються на поверхнях встановлення ходових коліс, а робоче зусилля стенда $\left(F_{3}\right)$, прикладене до буксових шийок, імітує навантаження з боку візка

12 ГОСТ 33200-2014. Оси колесных пар железнодорожного подвижного состава. Общие технические условия. Москва, 2015. 42 с.

${ }^{13}$ ГОСТ 33783-2016. Колесные пары железнодорожного подвижного состава. Методы определения показателей прочности. Москва, 2016. 58 с. 
(рис. 7a). Інша схема передбачає розташування опорних точок на буксових шийках із докладанням робочого зусилля стенда $\left(F_{4}\right)$ до поверхонь встановлення ходових коліс, що є імітацією впливу силової реакції колії на дію з боку візка (рис. 7б).

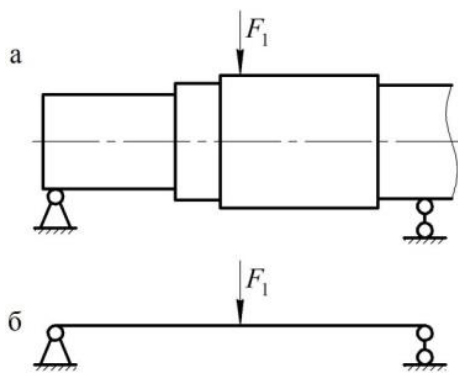

Рис. 5. Схема встановлення (а) та схема навантаження (б) осі КП за ГОСТ 33200

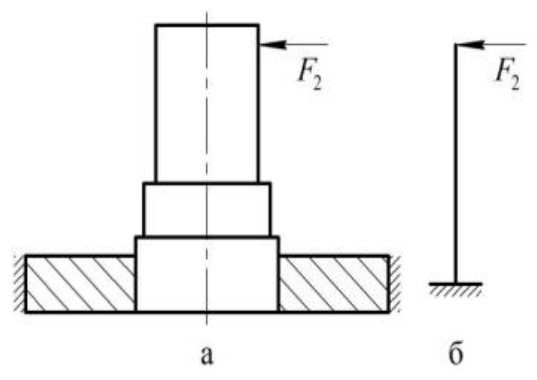

Рис. 6. Схема встановлення (а) та схема навантаження (б) осі КП за ГОСТ 33783
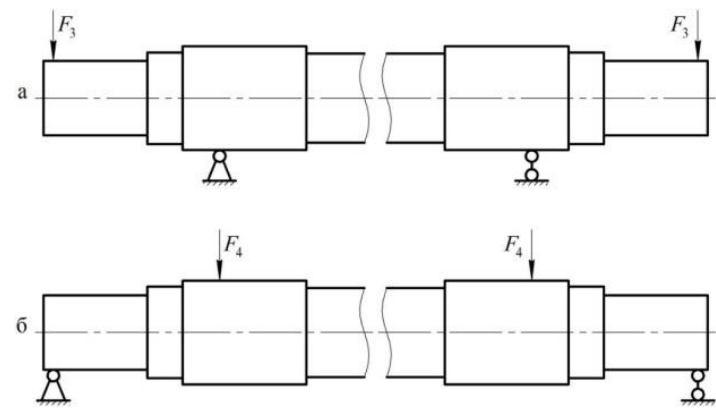

Рис. 7. Схеми встановлення осі КП, наближені до умов експлуатації

Спільним недоліком схем на рис. 7 є необхідність проведення випробувань осі в цілому, що суттєво збільшує габарити стенда в порівнянні зі схемами згідно з рис. 5, 6. Тому далі розглянемо лише перші дві схеми:

- «балка на двох опорах» (рис. 5б) - встановлення осі КП на двох шарнірних опорах із докладанням робочого зусилля в радіальному напрямку до поверхні встановлення ходового колеса, яка розташовується між опорами;

- «консольна балка» (рис. 6б) - фіксація осі КП через проміжну деталь (ходове колесо або технологічну маточину) з прикладанням консольного робочого зусилля стенда до буксової шийки. 
Для обгрунтування раціональної схеми навантаження приймаємо такі критерії:

- робоче зусилля стенда (i, як наслідок, енергоспоживання);

- поздовжній габарит стенда.

Кращою $є$ схема, за якої обидва критерії набувають найменших значень.

Порівняння за величиною робочого зусилля.

Під час здійснення випробувань на втомну міцність реалізується циклічне згинання осі КП. Незалежно від схеми навантаження, напруження згинання в будь-якому перерізі осі визначається за формулою:

$$
\sigma=M / W,
$$

де $M$ - згинальний момент у розрахунковому перерізі; $W$ - осьовий момент опору розрахункового перерізу.

Зважаючи на те, що момент опору $W$ залежить тільки від розмірів осі КП, вибір раціональної схеми навантаження здійснюємо за величиною згинального моменту.

Згинальний момент визначається так:

1) для схеми «балка на двох опорах»:

$$
M=0,5 F_{1} x,
$$

2) для схеми «консольна балка»:

$$
M=F_{2} x,
$$

У цих формулах $F_{1}$ і $F_{2}$ - робочі зусилля стенда для першої та другої схем навантаження відповідно; $x$ - координата розрахункового перерізу (однакова для обох схем).

3 наведених формул випливає, що за умови отримання однакових значень напруження згинання робоче зусилля стенда зі схемою навантаження 1 має бути у два рази більшим, ніж робоче зусилля стенда зі схемою навантаження 2. Тому за критерієм робочого зусилля стенда раціональною є схема навантаження «консольна балка».

Порівняння за поздовжнім габаритом стенда.

Поздовжній габарит стенда безпосередньо залежить від геометричних параметрів схеми навантаження (балки). Випробовується одна й та сама ділянка осі КП. Один кінець балки - торець буксової шийки; на ньому розташовується одна 3 шарнірних опор (для схеми «балка на двох опорах») або до нього прикладається консольне навантаження (для схеми «консольна балка»). Однак відстань від цього кінця балки до протилежного для різних схем навантаження не однакова. Другий кінець консольної балки (як точка) відповідає одному 202 
3 перерізів поверхні встановлення ходового колеса на осі КП, тоді як для балки на двох опорах ця точка розташовується далі, між двома поверхнями встановлення ходових коліс. Отже, довжина такої балки більша, тому за критерієм поздовжнього габариту стенда раціональною $\epsilon$ схема навантаження «консольна балка».

3 наведеного вище випливає, що за критеріями робочого зусилля (а отже й енергоспоживання) та поздовжнього габариту стенда раціональною $є$ схема навантаження «консольна балка», для якої вказані величини набувають найменших значень.

\section{2. Встановлення залежності робочого зусилля стенда від} параметрів осі колісної пари

Згідно 3 формулою (1), напруження згинання в перерізі осі, який характеризується координатою $x$, залежать від двох факторів: згинального моменту, який для обраної нами раціональної схеми навантаження («консольна балка») визначається за формулою (3), та осьового моменту опору розрахункового перерізу. Таким перерізом $\epsilon$ галтельний перехід від буксової шийки до уступу між шийкою та поверхнею встановлення ходового колеса (рис. 8).

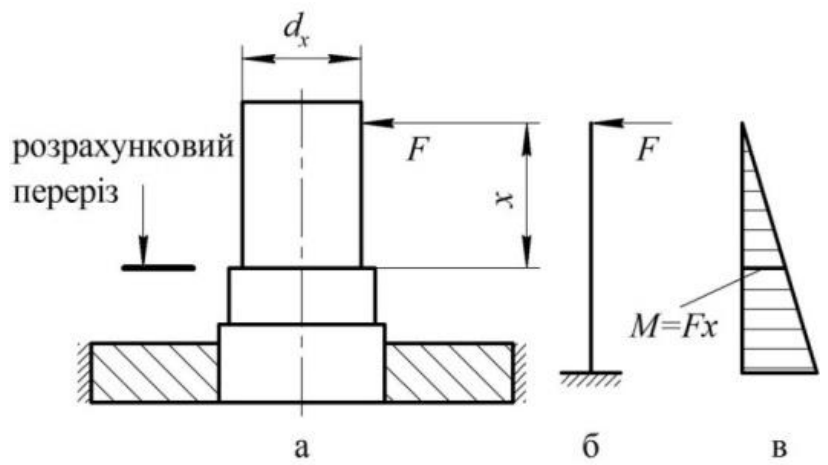

Рис. 8. Схема до визначення згинального моменту в розрахунковому перерізі: а - схема встановлення осі КП; б - схема навантаження; в епюра згинальних моментів

Осьовий момент опору розрахункового перерізу діаметром $d x$ визначається за формулою:

$$
W=\frac{\pi d_{x}^{3}}{32}
$$

Зважаючи на характер випробувань (випробування на втомну міцність) та особливості реалізації циклічного навантаження 
(за симетричним циклом), приймаємо $\sigma=\sigma_{-1}$, де $\sigma_{-1}-$ межа витривалості осі під час симетричного навантаження.

Поєднуючи формули (1), (3) й (4), маємо:

$$
\sigma=\frac{M}{W}=\frac{32 F x}{\pi d_{x}^{3}}=\sigma_{-1},
$$

Звідси робоче зусилля стенда:

$$
F=\frac{\pi d_{x}^{3}}{32 x} \sigma_{-1},
$$

Слід зауважити, що діаметр розрахункового перерізу $d_{x}$ та координата $x \in$ характеристиками осі КП, які нормуються відповідним стандартом $^{14}$. Межа витривалості $\sigma_{-1}$ встановлюється стандартом на випробування ${ }^{15}$, а тому для кожного типорозміру осі робоче зусилля стенда $F$ може бути наперед визначеним. 3 виразу (2.6) також випливає, що під час розробки стенда, який призначений для випробування осей кількох типорозмірів, необхідно передбачити не лише змінність геометрії досліджуваних зразків, а й різні величини робочого зусилля.

\section{3. Обгрунтування конструкції вібратора}

У межах роботи вібратором будемо називати елемент стенда, який створює робоче зусилля та забезпечує його прикладання до осі колісної пари.

Циклічне робоче зусилля стенда може бути прикладено до осі КП кількома способами:

1) за допомогою пульсатора (змінність зусилля за гармонічним законом);

2) шляхом обертання неврівноваженої маси (дебалансу) навколо нерухомої осі КП;

3) шляхом обертання осі КП зі встановленим на ній дебалансом;

4) за допомогою тиснення робочим органом стенда на вісь КП, яка обертається, 3 дотриманням постійної величини тиску, що відповідає амплітуді циклічного робочого зусилля.

Зважаючи на те, що робоче зусилля стенда має забезпечувати циклічне кругове згинання осі КП за симетричним циклом, доходимо

${ }^{14}$ ГОСТ 33200-2014. Оси колесных пар железнодорожного подвижного состава. Общие технические условия. Москва, 2015. 42 с.

${ }^{15}$ ГОСТ 33783-2016. Колесные пары железнодорожного подвижного состава. Методы определения показателей прочности. Москва, 2016. 58 с. 
висновку, що перший спосіб найскладніший з боку конструктивної реалізації вібратора.

Оскільки вісь КП є значно важчою за дебаланс, вібратор споживатиме більше енергії в разі докладання робочого зусилля стенда третім або четвертим способом.

Отже, за критеріями складності конструкції та енергоспоживання кращим є вібратор, який забезпечує докладання робочого зусилля стенда шляхом обертання неврівноваженої маси (дебалансу) навколо нерухомої осі КП. У разі його використання вказані критерії набувають найменших значень. Приймаємо його за основу для проведення подальших досліджень.

Вібратор має такі складові (рис. 9):

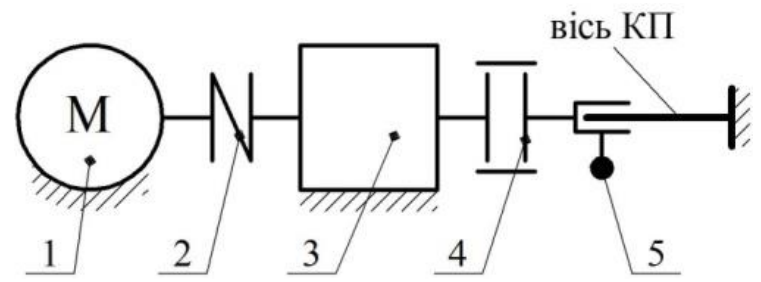

Рис. 9. Кінематична схема вібратора: 1 - двигун; 2 - пружна муфта; 3 - мультиплікатор; 4 - зубчаста муфта; 5 - дебаланс

За цих обставин мультиплікатор може бути відсутнім; у такому випадку тривалість випробувань, яка відповідає базі випробувань ${ }^{16}$, значно збільшується.

Принцип дії вібратора обраної конструкції грунтується на тому, що під час обертання дебалансу виникає сила, яка $є$ пропорційною до маси $(m)$, ексцентриситету (e) й кутової швидкості $(\omega)$ обертання дебалансу:

$$
F=m e \omega^{2},
$$

Вектор цієї сили постійний за величиною, а змінність його напрямку забезпечує кругове згинання осі КП.

\section{4. Визначення параметрів вібратора}

Основним елементом вібратора, який створює робоче зусилля стенда й визначає його величину, є дебаланс, що має такі параметри:

- форма;

${ }^{16}$ ГОСТ 33783-2016. Колесные пары железнодорожного подвижного состава. Методы определения показателей прочности. Москва, 2016. 58 с. 
- ексцентриситет (e);

- маса $(m)$

- кутова швидкість обертання $(\omega)$.

Перша й остання характеристики належать до ряду параметрів дебалансу доволі умовно: форму дебалансу неможливо виміряти (однак можна присвоїти їй порядковий номер), а кутова швидкість $\omega$ залежить від частоти обертання вала двигуна й передавального відношення мультиплікатора (зважаючи на незалежність цих значень, їхній безпосередній вплив на величину

Визначимо раціональні параметри дебалансу за умови дотримання певного робочого зусилля стенда $(F)$. Критерій раціональності енергоспоживання вібратора.

Maca $(m)$ та ексцентриситет (e) дебалансу пов'язані кількома залежностями:

1) робоче зусилля стенда відповідно до формули (7):

$$
F=m e \omega^{2},
$$

2) маса дебалансу:

$$
m=\gamma V(e)
$$

де $\gamma$ - густина матеріалу, з якого виготовлено дебаланс; $V(e)-$ об' $€$ м дебалансу як функція його ексцентриситету.

За умовою $\left(7^{*}\right)$ характер залежності маси дебалансу від його ексцентриситету гіперболічний. Об'єм дебалансу (а отже й маса) прямопропорційний до його ексцентриситету. Таким чином, виділення залежностей $m(e)$ з виразів (7*) і (8) дозволяє однозначно встановити параметри $m$ та $e$ для дебалансу будь-якої форми за певної частоти обертання $\omega$.

Для наочного представлення порядку встановлення раціональних значень параметрів дебалансу розглянемо тестовий приклад. Об'єкт випробувань - вісь типу РВ2Ш для вантажних вагонів. Розміри осі, необхідні для розрахунку ${ }^{17}$ (рис. 10$)$ :

- діаметр буксової шийки $d_{1}=150$ мм;

- довжина буксової шийки $l_{1}=210$ мм.

Товщину дебалансу приймаємо рівною ширині підшипника, на якому його буде встановлено. Через наявність перекосів осі КП під час випробувань будемо використовувати підшипник роликовий

${ }^{17}$ ГОСТ 33200-2014. Оси колесных пар железнодорожного подвижного состава. Общие технические условия. Москва, 2015. 42 с. 
радіальний сферичний дворядний № 3530 за ГОСТ 5721 із такими параметрами:

- внутрішній діаметр $d=d_{1}=150$ мм;

- зовнішній діаметр $D=270$ мм;

- ширина $B=73$ мм.

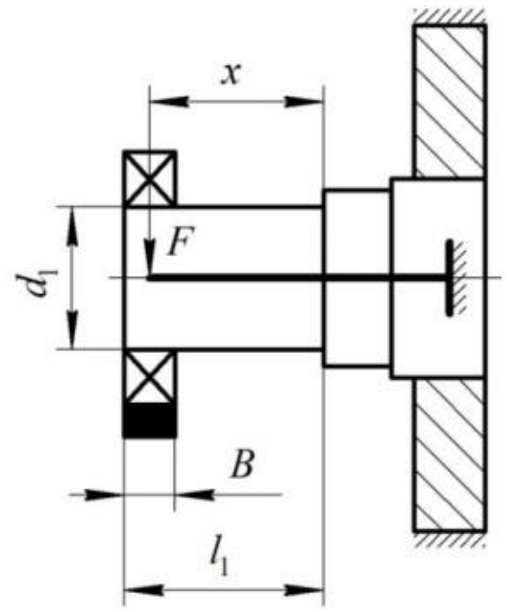

Рис. 10. Фрагмент осі КП і схема навантаження

Відповідно до прийнятих позначень, координата розрахункового перерізу на схемі навантаження:

$$
x=l_{1}-0,5 B,
$$

Згідно з формулою (6), робоче зусилля стенда:

$$
F=\frac{\pi d_{x}^{3}}{32 x} \sigma_{-1},
$$

де $d_{x}=d_{1}-$ діаметр розрахункового перерізу (місце галтельного переходу на буксовій шийці; див. рис. 8); $\sigma_{-1}=145$ МПа - межа витривалості осі в розрахунковому перерізі ${ }^{18}$.

Поєднуючи (6*) і (9), отримуємо:

$$
F=\frac{\pi d_{x}^{3}}{32\left(l_{1}-0,5 B\right)} \sigma_{-1},
$$

18 ГОСТ 33783-2016. Колесные пары железнодорожного подвижного состава. Методы определения показателей прочности. Москва, 2016. 58 с. 
Для тестового прикладу $F=274,4$ кН.

3 формули (7) характеристика дебалансу mе (добуток маси дебалансу і його ексцентриситету):

$$
m e=\frac{F}{\omega^{2}},
$$

Розрахунок виконуємо для трьох значень кутової швидкості обертання дебалансу за умови використання прямого приводу (без мультиплікатора). Для тестового прикладу маємо такі характеристики дебалансів:

$$
\begin{aligned}
& \text { - } \quad n_{1}=3000 \text { об } / \mathrm{xв} ; \omega_{1}=314 \mathrm{c}^{-1} ; m e_{1}=2,78 \mathrm{\kappa} \cdot \mathrm{M}, \\
& \text { - } \quad n_{2}=1500 \text { об/хв; } \omega_{2}=157 \mathrm{c}^{-1} ; m e_{2}=11,1 \kappa \Gamma \cdot \mathrm{M}, \\
& \text { - } \quad n_{3}=1000 \text { об } / \mathrm{xв} ; \omega_{3}=105 \mathrm{c}^{-1} ; m e_{3}=24,9 \text { кг } \cdot \mathrm{M},
\end{aligned}
$$

Застосування менших значень $\omega$ приводить до надмірної тривалості випробувань.

Розглянемо три типи дебалансів (рис. 11):

а) прямокутний;

б) круговий;

в) секторний.

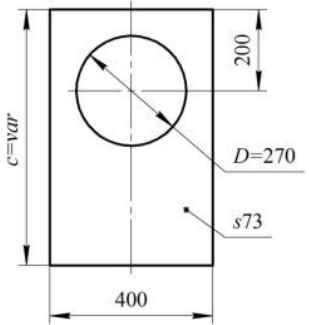

a

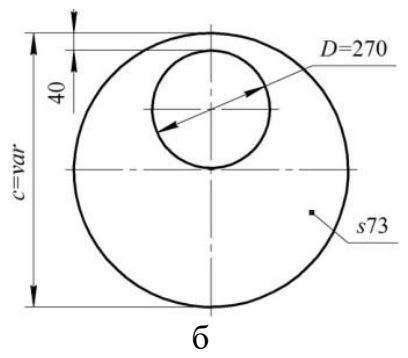

б

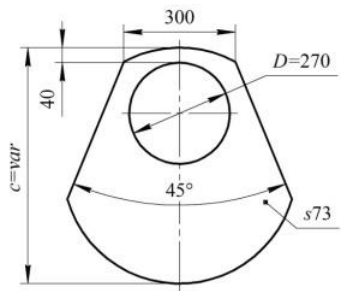

B

Рис. 11. Види дебалансів (розміри в мм): а - прямокутний;

б - круговий; в - секторний 
Вважаємо, що товщина кожного 3 дебалансів однакова й дорівнює ширині підшипника (для тестового прикладу $s=B=73$ мм).

Багатоваріантне 3D-моделювання дебалансів зі зміною величини $c$ $(c=v a r$, рис. 11$)$ дозволило отримати такі залежності $(m-$ в кг; $e-$ в м):

для прямокутного дебалансу:

$$
m(e)=379 e+54,77,
$$

для кругового дебалансу:

$$
m(e)=705 e^{2}+242 e+21,6,
$$

для секторного дебалансу:

$$
m(e)=877 e^{2}+338 e+20,8,
$$

Графічне представлення функцій (12)-(14) і (15)-(17) в одній координатній площині дозволяє встановити масу $m$ та ексцентриситет $e$ кожного $з$ видів дебалансів, які забезпечують необхідне значення робочого зусилля стенда. Величини $m$ та $e \epsilon$ координатами точок перетину відповідних кривих (рис. 12). Результати аналізу графіка подано в табл. 1.

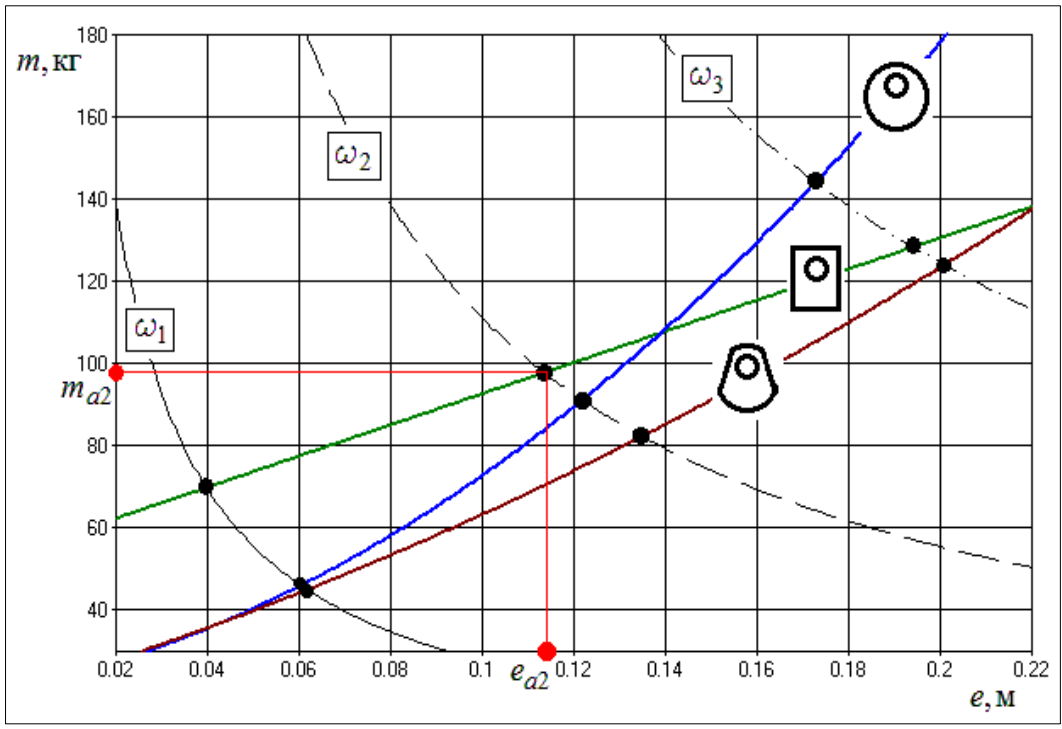

Рис. 12. Графік для визначення маси та ексцентриситету дебалансу 
Таблиця 1

Параметри дебалансів

\begin{tabular}{|c|c|c|c|c|c|c|c|c|c|}
\hline \multirow{2}{*}{$\omega, \mathrm{c}^{-1}$} & \multicolumn{3}{|c|}{ Прямокутний дебаланс } & \multicolumn{2}{|c|}{ Круговий дебаланс } & \multicolumn{3}{|c|}{ Секторний дебаланс } \\
\cline { 2 - 11 } & $m$, кг & $e, \mathrm{M}$ & $I, \mathrm{\kappa} \cdot \mathrm{M}^{2}$ & $m$, кг & $e, \mathrm{M}$ & $I, \mathrm{\kappa} \cdot \mathrm{M}^{2}$ & $m$, кг & $e, \mathrm{M}$ & $I, \mathrm{\kappa} \cdot \mathrm{M}^{2}$ \\
\hline$\omega_{1}=314$ & 69,9 & 0,037 & 2,86 & 46,3 & 0,060 & 1,54 & 44,5 & 0,064 & 1,47 \\
\hline$\omega_{2}=157$ & 97,2 & 0,114 & 5,89 & 90,7 & 0,119 & 4,89 & 81,6 & 0,133 & 4,42 \\
\hline$\omega_{3}=105$ & 128,0 & 0,191 & 12,23 & 144,9 & 0,171 & 12,00 & 125,2 & 0,198 & 10,78 \\
\hline
\end{tabular}

Визначимо енергію, яка витрачається на обертання дебалансу, за формулою:

$$
E=0,5 I \omega^{2},
$$

Результати розрахунків зводимо до табл. 2.

Таблиця 2

Витрати енергії на обертання дебалансу

\begin{tabular}{|c|c|c|c|}
\hline \multirow{2}{*}{$\omega, \mathrm{c}^{-1}$} & \multicolumn{3}{|c|}{$E$, кДж, для дебалансу } \\
\cline { 2 - 4 } & прямокутного & кругового & секторного \\
\hline$\omega_{1}=314$ & 141,0 & 75,9 & 72,5 \\
\hline$\omega_{2}=157$ & 72,6 & 60,3 & 54,6 \\
\hline$\omega_{3}=105$ & 67,4 & 66,2 & 59,4 \\
\hline
\end{tabular}

Як бачимо, найменшими є витрати енергії на обертання секторного дебалансу з кутовою швидкістю $\omega_{2}=157 \mathrm{c}^{-1}$.

Дослідження показали, що подальше збільшення частоти обертання дебалансу приводить до зменшення його маси, ексцентриситету й моменту інерції. Однак за високих кутових швидкостей обертання дебалансу на величину робочого зусилля стенда починають впливати неточності виготовлення та монтажу осі КП та елементів вібратора. Так, під час використання (в конструкції вібратора) двигуна з частотою обертання вала $n \approx 3000$ об/хв і мультиплікатора 3 передавальним відношенням $u \approx 1 / 15$ отримуємо $\omega=4710 \mathrm{c}^{-1}$. За таких умов ексцентриситет секторного дебалансу $e=5,9 \cdot 10^{-4}$ м, що за порядком величин збігається $з$ допуском на биття осі КП.

Аналізуючи отримані результати, доходимо висновку, що за критерієм енергоспоживання раціональним є секторний дебаланс, який обертається 3 кутовою швидкістю біля $150 \mathrm{c}^{-1}$. За такої умови маса дебалансу становить близько 80 кг, а ексцентриситет - 135 мм. На цім вказаний критерій набуває найменшого значення. 


\section{ВИСНОВКИ}

Аналіз чинної нормативної бази показав, що одними 3 основних видів випробувань колісних пар рейкового транспорту є випробування на міцність їх елементів - коліс та осей, у тому числі з визначенням показників втомної міцності.

Випробування коліс на втомну міцність доцільно проводити 3 використанням стендового обладнання, яке забезпечує прикладання циклічно змінного робочого зусилля 3 коефіцієнтом асиметрії 0,1 . Значення зусилля встановлюється методиками випробувань.

Для проведення стендових випробувань на втомну міцність осей колісних пар рейкового транспорту раціональною $\epsilon$ схема навантаження «консольна балка», за якою критерії раціональності (робоче зусилля, енергоспоживання та поздовжній габарит стенда) набувають найменших значень.

Робоче зусилля стенда залежить від розмірів осі КП (діаметру й довжини буксової шийки), тому універсальний стенд для випробувань має передбачати можливість зміни робочого зусилля в залежності від типорозміру осі.

За критеріями складності конструкції та енергоспоживання кращим $\epsilon$ вібратор, який забезпечує докладання робочого зусилля стенда шляхом обертання неврівноваженої маси (дебалансу) навколо нерухомої осі КП. У разі його використання вказані критерії набувають найменших значень.

За критерієм енергоспоживання раціональною $\epsilon$ конструкція вібратора із секторним дебалансом, який обертається 3 кутовою швидкістю біля $150 \mathrm{c}^{-1}$. На цім маса дебалансу становить близько 80 кг, а ексцентриситет - 135 мм. За таких умов вказаний критерій набуває найменшого значення.

\section{АНОТАЦІЯ}

Для проведення лабораторних випробувань колісних пар рейкового транспорту, визначення характеристик міцності й ресурсних характеристик їх елементів, порівняння ефективності конструктивних рішень і проведення приймальних випробувань доцільно застосовувати стендове обладнання, що дозволить максимально оцінити різні властивості КП. Тому тематика досліджень, що пов'язана зі створенням та удосконаленням конструкцій стендового обладнання для експериментальних досліджень колісних пар, є актуальною науковоприкладною задачею для залізничного транспорту й транспортного машинобудування. У роботі розглянемо особливості проведення стендових випробувань колісних пар із метою визначення показників втомної міцності їхніх елементів. Проведені авторами дослідження 
показали, що випробування коліс на втомну міцність доцільно проводити 3 використанням стендового обладнання, яке забезпечує прикладання циклічно змінного робочого зусилля 3 коефіцієнтом асиметрії 0,1 (значення зусилля встановлюеться методиками випробувань). Для проведення стендових випробувань на втомну міцність осей колісних пар рейкового транспорту раціональною $є$ схема навантаження «консольна балка». Робоче зусилля стенда має реалізовуватися шляхом обертання секторного дебалансу навколо нерухомої осі КП із частотою біля $150 \mathrm{c}^{-1}$, на цім його маса має становити близько 80 кг, а ексцентриситет - 135 мм.

\section{ЛІТЕРАТУРА}

1. ГОСТ 11018-2011. Колесные пары тягового подвижного состава железных дорог колеи 1520 мм. Общие технические условия. Москва, 2012. $27 \mathrm{c}$.

2. ГОСТ 4835-2013. Колесные пары железнодорожных вагонов. Технические условия. Москва, 2014. 32 с.

3. ГОСТ 31847-2012. Колесные пары специального подвижного состава. Общие технические условия. Москва, 2013. 23 с.

4. ГОСТ 31373-2008. Колесные пары локомотивов и моторвагонного подвижного состава. Расчеты и испытания на прочность. Москва, 2009. 13 с.

5. ГОСТ 33783-2016. Колесные пары железнодорожного подвижного состава. Методы определения показателей прочности. Москва, 2016. $58 \mathrm{c}$.

6. Specification M-107/M-208. Wheels, Carbon Steel. AAR Manual of Standards and Recommended Practices. Wheels and Axles. 2011. P. 21-60.

7. ГОСТ 10791-2011. Колеса цельнокатаные. Технические условия. Москва, 2011.27 с.

8. Стенд для випробувань залізничних коліс на втомну міцність : пат. 136718 Україна ; опубл. 27.08.2019.

9. Novosad M., Fajkoš R., Řeha B., Řezníček R. Fatigue tests of railway axles. Procedia Engineering. 2010. № 2. P. 2259-2268. https://doi.org/ 10.1016/j.proeng.2010.03.242.

10. Raksha S., Anofriev P., Kuropiatnyk O. Simulation modeling of the rolling stock axle test-bench. E3S Web of Conferences. 2019. № 123. Art. No 01032. https://doi.org/10.1051/e3sconf/201912301032.

11. Raksha S.V., Anofriev P.G., Bohomaz V.M., Kuropiatnyk O.S. Mathematical and S-models of cargo oscillations during movement of bridge crane. Naukovyi Visnyk Natsionalnoho Hirnychoho Universytetu. 2019. № 2. P. 108-115. https://doi.org/10.29202/nvngu/2019-2/16.

12. Установка для испытания осей колесных пар на усталость при круговом изгибе : пат. 1076816 СССР ; опубл. 28.02.1984. 
13. Стенд для испытания колес и осей колесных пар на сопротивление усталости : пат. 2650327 Россия ; опубл. 11.04.2018.

14. Стенд для испытания колес и осей колесных пар на сопротивление усталости и способ проведения испытаний : пат. 2651629 Россия ; опубл. 23.04.2018.

15.ГОСТ 33200-2014. Оси колесных пар железнодорожного подвижного состава. Общие технические условия. Москва, 2015. 42 с.

\section{Information about authors:}

Raksha S. V.,

Doctor of Technical Sciences, Professor, Head of the Department of Applied Mechanics and Materials Science

Dnipro National University of Railway Transport named after Academician V. Lazaryan

2, Lazaryana str., Dnipro, 49010, Ukraine

Kuropiatnyk O. S.,

Candidate of Technical Sciences, Associate Professor,

Associate Professor at the Department of Applied Mechanics and Materials Science Dnipro National University of Railway Transport named after Academician V. Lazaryan

2, Lazaryana str., Dnipro, 49010, Ukraine 